\title{
Delivering the Goods: An Interview with Best Buy and EIX Founder Dick Schulze
}

\author{
James C Wetherbe (Texas Tech University)
}

KEYWORDS: Wholesale Trade, Retail Trade,

Entrepreneurship, Management, Negotiation, Leadership, Strategy, Family Business, Learn From Leaders.

Dick Schulze, the founder of Best Buy and EIX, shares his experiences as an entrepreneur and innovator, including how he tripled his income from his boyhood paper route; quit a retail job when his ideas were not valued; started one consumer electronics store, Sound of Music; then transformed that into Best Buy, the largest consumer electronics store chain in the world.

His lessons of finding opportunities in the ruins of dashed plans -- in Schulze's case, a tornado that destroyed Sound of Music but gave birth to the idea for Best Buy -- still resonate today in a new era of uncertainty. 